\title{
AKTIVITAS ANTIANGIOGENESIS EKSTRAK BERAS HITAM \\ (Oryza sativa L. indica) PADA CHORIOALANTOIC MEMBRANE (CAM) SEBAGAI KANDIDAT ANTIKANKER
}

\section{ANTIANGIOGENESIS ACTIVITY OF BLACK RICE (Oryza sativa L. indica) ON CHORIOALANTOIC MEMBRANE (CAM) AS ANTICANCER CANDIDATE}

\author{
Fitria Diniah Janah Sayekti ${ }^{1}$, Muhammad Taufiq Qurrohman ${ }^{2}$ \\ ${ }^{1,2}$ Sekolah Tinggi Ilmu Kesehatan Nasional \\ E-mail korespondensi : fitria.diniah@stikesnas.ac.id
}

\begin{abstract}
Abstrak
Angiogenesis memberikan kontribusi pada karsinogenesis atau pertumbuhan sel kanker yang tidak terkendali. Pertumbuhan tumor atau kanker dapat dikontrol melalui penghambatan angiogenesis. Salah satu bahan alam yang berpotensi sebagai bahan pangan fungsional prevensi kanker adalah beras hitam. Penelitian ini bertujuan untuk mempelajari dan mengetahui aktivitas antiangiogenesis ekstrak beras hitam (Oryza sativa L. indica) pada Chorioallantoic Membrane (CAM) sebagai kandidat antikanker. Parameter yang diamati dalam penelitian adalah banyaknya pembuluh darah baru atau respon angiogenesis pada CAM setelah pemberian ekstrak beras hitam dengan konsentrasi masing-masing 20, 25, 50, 60 dan $75 \mu \mathrm{g} / \mathrm{mL}$. Ekstrak beras hitam menghambat pembentukan pembuluh darah pada CAM. Rata-rata jumlah pembuluh darah pada konsentrasi ekstrak beras hitam 20, 25, 50, 60 dan $75 \mu \mathrm{g} / \mathrm{mL}$ berturut-turut adalah 27,$6 ; 21,0 ; 3,67 ; 3,0 ; 2,0$. Pada kontrol dengan larutan $\mathrm{NaCl} 0,9 \%$, jumlah rata-rata pembuluh darah adalah adalah 35,33 .
\end{abstract}

Kata Kunci : Beras hitam (Oryza sativa L. indica), angiogenesis, antikanker

\begin{abstract}
Angiogenesis contributes to uncontrolled carcinogenesis or cancer cell growth. Tumor or cancer growth can be controlled through inhibition of angiogenesis. One of the natural ingredients that have the potential as a cancer prevention functional food ingredient is black rice. This study aims to study and determine the antiangiogenesis activity of black rice extract (Oryza sativa L. indica) on the Chorioallantoic Membrane (CAM) as an anticancer candidate. The parameters observed in the study were the number of new blood vessels or the response of angiogenesis to CAM after the administration of black rice extract with a concentration of 20, 25, 50, 60 and $75 \mu \mathrm{g} / \mathrm{mL}$, respectively. The higher the concentration of black rice extract showed a decrease in the number of blood vessels formed. The average number of blood vessels at concentrations of black rice extract 20, 25, 50, 60 and $75 \mu \mathrm{g} / \mathrm{mL} \mathrm{were} \mathrm{27.6;21.0;}$ $3.67 ; 3.0 ; 2.0$. In the control with $0.9 \% \mathrm{NaCl}$ solution, the average number of blood vessels was 35.33 .
\end{abstract}

Keywords: Black rice (Oryza sativa L. indica), angiogenesis, anticancer

\section{PENDAHULUAN}

Kanker merupakan penyakit yang ditandai dengan pertumbuhan sel yang tidak terkendali. Sel kanker mempunyai kemampuan untuk menghindari apoptosis, menghindari sinyal yang menekan pembentukan pembuluh darah baru (angiogenesis), dan memiliki kemampuan untuk mengadakan invasi dan metastasis (McDonald, 2008). Kanker dikelompokkan sebagai penyakit terminal karena pengobatan yang diberikan, baik kemoterapi, radioterapi, imunoterapi maupun terapi gen, sampai saat ini belum memberikan hasil yang memuaskan (Abidin, 2017). Kanker merupakan penyebab kematian kedua di dunia setelah penyakit kardiovaskuler. Pada tahun 2005, WHO memperkirakan setiap tahun 12 juta orang di seluruh dunia menderita kanker dan 7,6 juta di antaranya meninggal dunia.

Angiogenesis adalah proses pembentukan pembuluh darah baru yang terjadi secara normal dan sangat penting dalam proses pertumbuhan dan perkembangan. Angiogenesis diketahui merupakan kunci bagi perkembangan sel kanker (Giavazzi et al., 2000). Angiogenesis memberikan kontribusi pada karsinogenesis atau pertumbuhan sel kanker yang tidak terkendali dan bersifat ganas (Hamid dkk, 2013). Menurut Salamah dkk., (2010) angiogenesis memungkinkan sel kanker mendapatkan suplai nutrisi dan oksigen, sehingga dapat terus bertahan hidup. Angiogenesis sangat penting untuk 
viabilitas, pertumbuhan, invasi, dan metastase tumor.

Berdasarkan penelitian Salem et al., (2015) dapat diketahui bahwa pertumbuhan tumor atau kanker dapat dikontrol melalui penghambatan angiogenesis. Menurut Kilarski et al., (2012) terapi penghambatan angiogenesis dapat digunakan sebagai pengobatan antikanker. Tanpa angiogenesis, tumor segera menyusut dan terkadang menghilang. Pengobatan kanker melalui penghambatan angiogenesis lebih efektif dalam mengobati kanker dari pada membunuh sel kanker secara langsung. Penghambatan angiogenesis juga akan mengakibatkan hambatan distribusi nutrisi dan oksigen ke sel kanker (Raffi, 2002).

Chorioallantoic membrane (CAM) assay merupakan metode yang dianggap sangat bernilai untuk mengetahui efek antiangiogenik dari suatu obat atau substansi lainnya (Yildiz et al, 2013). Menurut Auerbach et al., (2003) CAM assay dapat digunakan untuk mengevaluasi potensi pro-angiogenik dan anti-angiogenik dari suatu molekul. Salah satu bahan alam yang berpotensi sebagai bahan pangan fungsional prevensi kanker adalah beras hitam (Oryza sativa L. indica). Beras hitam sekarang ini mulai banyak dikonsumsi karena mengandung berbagai metabolit sekunder diantaranya antosianin yang dapat berfungsi salah satunya sebagai antioksidan (Kristamtini, 2014). Ekstrak bekatul beras hitam diketahui memiliki aktivitas antioksidan (Kaneda et al., 2006). Beras hitam mempunyai kandungan senyawa fenol dan antosianin yang lebih tinggi dari jenis beras lainnya, seperti beras putih dan beras merah. Berbagai penelitian juga menunjukkan kemampuan beras hitam untuk menghambat pertumbuhan beberapa jenis kanker. Fraksi ekstrak metanolik dari bekatul beras hitam memiliki aktivitas sitotoksik terhadap sel T47D dan WiDr serta mampu menginduksi apoptosis lebih tinggi dibandingkan doxorubicin. Ekstrak beras hitam juga mampu menginduksi apoptosis bagi sel HL-60, MCF-7, dan Caco-2 serta menghambat proliferasi sel HL-60, sel MCF-7 dan sel Caco-2. Menurut Takashima et al., (2013) ekstrak air dan metanolik beras hitam mampu menghambat proliferasi sel kanker kolon LS174T. Penelitian ini bertujuan untuk mengetahui potensi antikanker beras hitam berdasarkan aktivitas antiangiogenesis pada Chorioallantoic Membrane (CAM).

\section{METODE}

a. Alat dan Bahan

Rotary evaporator, bejana, timbangan, oven, blender, saringan, mikropipet, autoclave, inkubator, kaca pembesar, kamera, mini drill, senter, alat-alat gelas, beras hitam, telur ayam berembrio, alcohol 96\%, alcohol 70\%, $\mathrm{NaCl} 0,9 \%$, aquadest, kertas saring, alumunium foil, wrapping.

b. Pembuatan Ekstrak Beras Hitam (Oryza sativa $\mathrm{L}$. indica)

Beras hitam yang digunakan dioven dengan suhu $50^{\circ} \mathrm{C}$ kemudian diblender hingga menjadi serbuk halus setelah itu dilakukan proses maserasi. Maserasi dilakukan dengan cara merendam serbuk simplisia dengan pelarut etanol $70 \%$, perendaman dilakukan selama 3 hari dengan penggantian pelarut setiap 24 jam sekali dan dilakukan pengadukan selama beberapa kali. Maserat yang didapat dari rendaman serbuk simplisia disaring dengan kertas saring. Setelah itu, ekstrak dipisahkan dari pelarutnya dengan cara penguapan menggunakan rotary evaporator dengan suhu $50^{\circ} \mathrm{C}$ sampai diperoleh ekstrak yang pekat.

c. Persiapan Chorioallantoic Membrane (CAM)

Telur ayam berembrio umur 8 hari diinkubasi dalam inkubator laboratorium pada suhu $39^{\circ} \mathrm{C}$. Tahap awal yaitu dengan memberi tanda pada kulit telur yang meliputi batas ruang udara, lokasi embrio dan daerah yang akan dibuat segi empat (jendela) berukuran $1 \times 1 \mathrm{~cm}$ di atas embrio. Lokasi embrio diketahui melalui candling pada telur. Pada kedua daerah tersebut di usap menggunakan alcohol dan dibuat lubang kecil.Melalui lubang ini 
bahan uji diimplantasi ke dalam CAM yang telah terbentuk.

d. Uji Aktivitas Antiangiogenesis Beras Hitam Semua peralatan yang digunakan untuk uji antiangiogenesis disterilisasi dengan autoclav, suhu $121^{\circ} \mathrm{C}$ selama $15-30$ menit. Subyek uji berupa telur ayam berembrio dibagi dalam 6 kelompok dengan tiga ulangan, sebagai berikut: kelompok I kelompok kontrol dengan implantasi paper disc dengan pelarut sebanyak 10 $\mu \mathrm{L}$, kelompok II sampai VI merupakan telur dengan perlakuan ekstrak beras hitam dengan konsentrasi berturut-turut $20 \mu \mathrm{g} / \mathrm{mL}, 25 \mu \mathrm{g} / \mathrm{mL}, 50 \mu \mathrm{g} / \mathrm{mL}, 60 \mu \mathrm{g} / \mathrm{mL}$, $75 \mu \mathrm{g} / \mathrm{mL}$. Setelah diberi perlakuan, telur diinkubasi pada suhu $39{ }^{\circ} \mathrm{C}$ dengan kelembaban relatif $60 \%$ selama 3 hari atau 72 jam (Ribbati et al., 1997), kemudian telur dibuka (umur 12 hari) dan isi telur dikeluarkan. Telur dibuka dengan cara menggunting cangkang telur menjadi 2 bagian dimulai dari cangkang yang dekat dengan rongga udara, setelah itu CAM yang melekat pada cangkang diamati secara makroskopik. Pengamatan secara makroskopik dilakukan dengan bantuan kaca pembesar.

e. Analisis Data

Parameter yang diamati dalam penelitian adalah banyaknya pembuluh darah baru atau respon angiogenesis pada CAM setelah pemberian ekstrak beras hitam. Evaluasi efek antiangiogenesis secara makroskopik dilakukan dengan menghitung jumlah pembuluh darah baru. Pembentukan pembuluh darah baru yang dihitung adalah cabang terkecil terakhir baik yang muncul dari pembuluh darah utama maupun dari cabang pembuluh darah ke 2 dan ke 3 . Pembuluh darah utama adalah pembuluh darah yang paling besar dan keluar dari embrio.

\section{HASIL DAN PEMBAHASAN}

Angiogenesis merupakan peristiwa pertumbuhan pembuluh darah baru (neovaskularisasi) yang memungkinkan sel kanker mendapatkan suplai nutrien dan oksigen, sehingga dapat berkembang dan bermetastase (Kilarski et al., 2012).

Berdasarkan data hasil penelitian menunjukkan bahwa jumlah pertumbuhan pembuluh darah baru pada CAM embrio ayam menurun sesuai dengan peningkatan dosis. Perhitungan rata-rata jumlah pembuluh darah pada penelitian ini dilakukan secara makroskopis dengan menghitung pembuluh darah yang muncul disekitar embrio ayam. Konsentrasi ekstrak beras hitam yang digunakan dalam penelitian ini adalah 20, 25, 50, 60 dan $75 \mu \mathrm{g} / \mathrm{mL}$ dan kontrol dengan hanya pemberian $\mathrm{NaCl} 0,9 \%$. Rata-rata jumlah pembuluh darah dari masing-masing konsentrasi berturut-turut adalah 27,6; 21,0; 3,67; 3,0; 2,0. Jumlah pembuluh darah rata-rata pada kontrol yang hanya diberikan larutan $\mathrm{NaCl} 0,9 \%$ adalah 35,33 . 


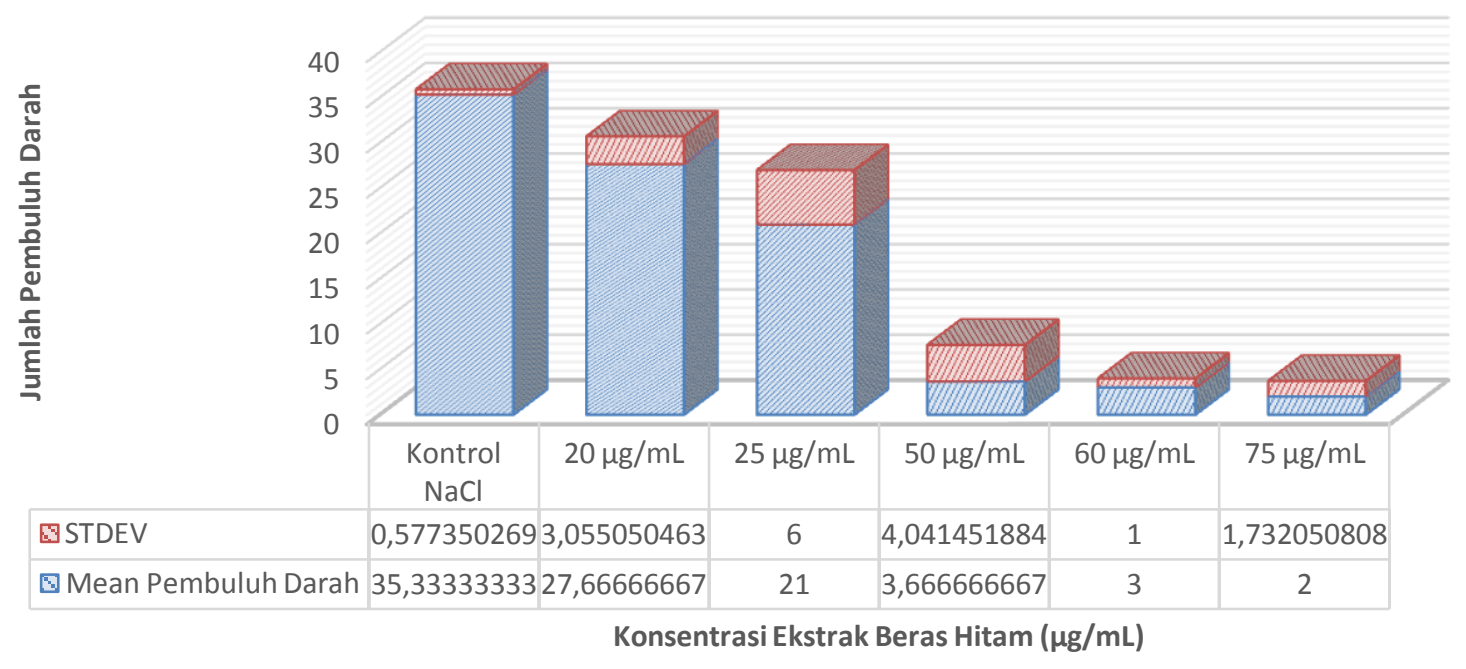

Gambar 2. Jumlah Pembuluh Darah dengan Perlakuan Ekstrak Beras Hitam

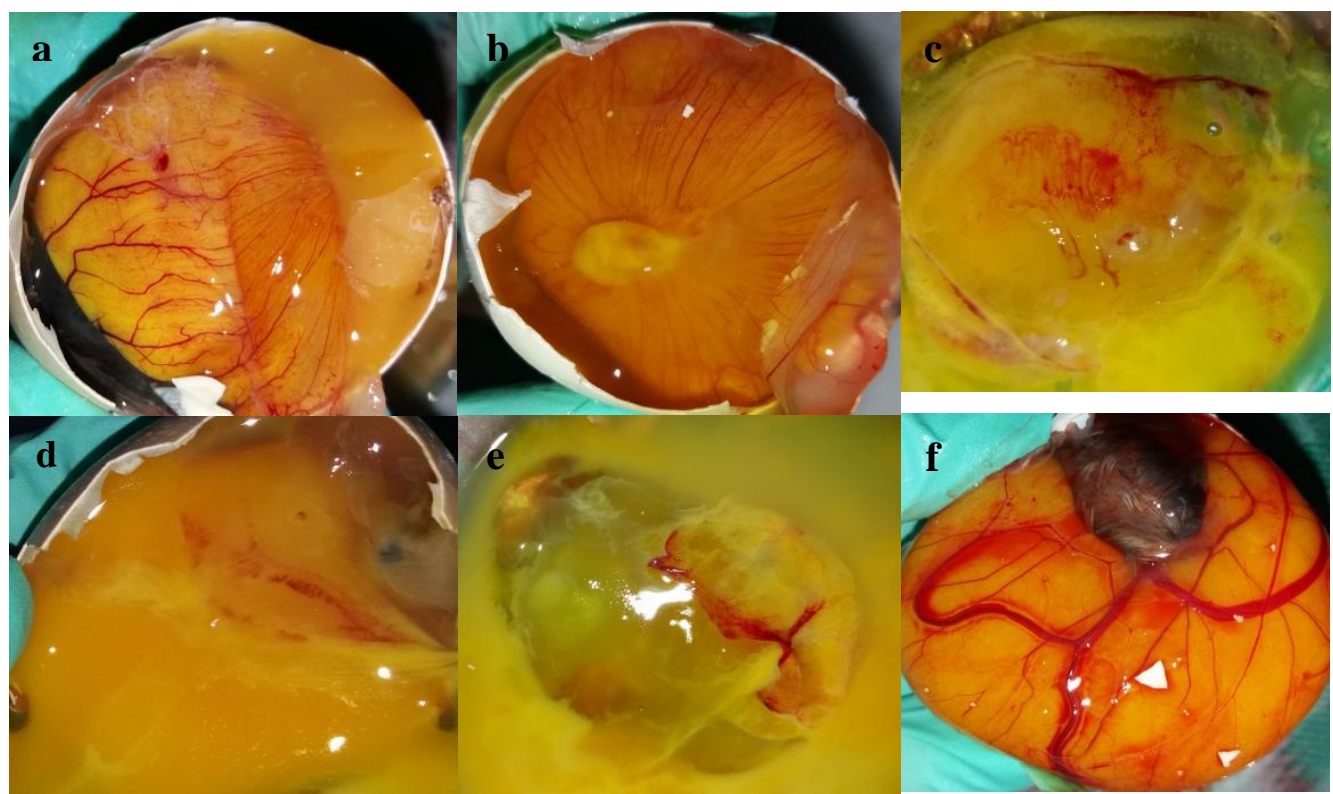

Gambar 3. Makroskopis pembuluh darah pada CAM dengan perlakuan ekstrak beras hitam Keterangan: a. Konsentrasi $20 \mu \mathrm{g} / \mathrm{mL}$; b. $25 \mu \mathrm{g} / \mathrm{mL}$; c. $50 \mu \mathrm{g} / \mathrm{mL}$, d. $60 \mu \mathrm{g} / \mathrm{mL}$; e. $75 \mu \mathrm{g} / \mathrm{mL}$; f. kontrol $\mathrm{NaCl}$

Gambaran makroskopis pembuluh darah pada CAM dengan perlakuan ekstrak beras hitam dapat dilihat pada gambar 3. Hasil pengamatan makroskopis memperlihatkan bahwa semakin tinggi konsentrasi ekstrak beras hitam, penghambatan angiogenesis juga semakin besar. Hal ini dapat dilihat dari kepadatan pembuluh darah yang terbentuk. Pada CAM dengan pemberian ekstrak beras hitam dengan konsentrasi $20 \mu \mathrm{g} / \mathrm{mL}$ menunjukkan jumlah pembuluh darah yang paling besar dibandingkan dengan konsen- trasi lainnya. Pada konsentrasi $50 \mu \mathrm{g} / \mathrm{mL}$ memperlihatkan gambaran penurunan jumlah pembuluh darah yang cukup besar dibandingkan dengan kontrol menggunakan $\mathrm{NaCl}$. Secara makroskopis jumlah pembuluh darah mengalami penurunan pada konsentrasi ekstrak beras hitam yang semakin tinggi.

Perlakuan pemberian ekstrak beras hitam melalui CAM dapat lebih mudah dan cepat untuk mencapai mencapai endotel dibandingkan memalui rute lainnya.Menurut (Ribatti et al., 2000) chorioalantoic 
membrane memiliki membran tipis dan bening yang terdiri dari 2 lapis epitel yang dipisahkan oleh jaringan ikat. Chorioalantoic membrane merupakan gabungan membran korion dan alantois yang memiliki banyak vaskularisasi darah sehingga baik digunakan sebagai model untuk melihat potensi senyawa antikanker pada suatu bahan, dalam penelitian ini menggunakan ekstrak beras hitam, melalui penghambatan angiogenesis.

Proses tahap awal perangsangan pembentukan pembuluh darah baru pada kanker dimulai dari difusi faktor pertumbuhan pembuluh darah yang dikeluarkan kanker menuju reseptor yang ada di permukaan sel endotel. Setelah mencapai sel endotel dan berikatan dengan reseptor-nya, faktor pertumbuhan pembuluh darah tersebut akan menyebabkan endotel teraktivasi. Teraktivasinya endotel menyebabkan pembengkakan serta peningkatan permeabilitas vaskuler. Peningkatan permeabilitas vaskuler menyebabkan ekstravasasi plasma darah ke luar lumen pembuluh darah.

Menurut Chilmy dkk., (2012), selain pembengkakan sel endotel dan peningkatan permeabilitas kapiler, aktivasi endotel menyebabkan endotel mengeluarkan suatu zat pendegradasi protein, yaitu enzim matrix metalloproteinase (MMP). Enzim MMP yang bekerja pada proses angiogenesis adalah enzim MMP-2 dan MMP-9 yang secara spesifik berfungsi untuk mendegradasi kolagen tipe IV, laminin-5, membantu sel-sel kanker bermetastase, dan menyebabkan peningkatan pertumbuhan tumor dengan membentuk ruangan yang penting. Rasio peningkatan matrix metalloproteinase-9 (MMP-9) dari bentuk aktif ke laten berhubungan dengan progresi tumor pada kanker-kanker invasive. Begitu enzim MMP dikeluarkan oleh sel endotel sasaran pertama adalah membran basalis, dan ketika membran basalis telah terdegradasi endotelendotel akan lepas dan bermigrasi kearah membrane yang terdegradasi tersebut. Awalnya endotel akan berkumpul lalu berproliferasi di tempat tersebut, lama-kelamaan akan tersusun prekursor-prekursor pembuluh darah yang lain yaitu membran basalis serta otot polos.

Salah satu kandungan ekstrak beras hitam yang berpotensi sebagai antikanker adalah antioksidan. Menurut Kaneda et al., (2006) ekstrak beras hitam diketahui memiliki aktivitas antioksidan. Beras hitam sebagai bahan pangan fungsional mulai banyak dikonsumsi karena mengandung berbagai metabolit sekunder diantaranya antosianin yang dapat berfungsi salah satunya sebagai antioksidan (Kristamtini, 2014). Beras hitam mempunyai kandungan senyawa fenol dan antosianin yang lebih tinggi dari jenis beras lainnya, seperti beras putih dan beras merah.

Berdasarkan hasil penelitian dapat diketahui bahwa jumlah pembuluh darah yang terbentuk pada CAM embrio ayam menurun sesuai dengan peningkatan dosis. Hal tersebut dapat dilihat pada gambaran makroskopis CAM yang menunjukkan bahwa semakin tinggi konsentrasi ekstrak beras hitam jumlah pembuluh darah yang terbentuk semakin sedikit.Pada penelitian ini, senyawa khusus pada ekstrak beras hitam yang berperan dalam penghambatan angiogenesis untuk antikanker belum diketahui secara pasti dan masih perlu dilakukan penelitian lebih lanjut.

\section{SIMPULAN}

Ekstrak beras hitam dapat menghambat pembentukan pembuluh darah pada CAM. Semakin tinggi konsentrasi ekstrak beras hitam menunjukkan penurunan jumlah pembuluh darah yang terbentuk.

\section{DAFTAR PUSTAKA}

Abidin, Z. Potensi antikanker payudara ekstrak etanol beras hitam (Oryza sativa L. indica) dalam menurunkan kadar ca $15-3$ serum pada tikus putih eticul dawley yang diinduksi7,12dimethylbenz $(\alpha)$ antracene (dmba) dan estrogen. Qanun Medika 2017; 1 (1). 
Auerbach R, Lewis R, Shinners B, Kubai L, Akhtar N. Angiogenesis assays: a critical overview. Clinical Chemistry 2003; 49 (1): 32-40.

Chilmy M, Munawir A, Misnawi. Efek antiangiogenik ekstrak polifenol biji kakao (Theobroma cacao) pada membran korio alantois (cam) embrio ayam. Fakultas Kedokteran, Universitas Jember. Artikel Ilmiah Hasil Penelitian Mahasiswa 2012.

Giavazzi R, Albini A, Bussolino F, DeBraud F, Presta $M$, Ziche $M$, Costa $A$. The biological basis for antiangiogenic therapy.European Journal ofCancer 2012; 36: 1913-1918.

Hamid IS, Nazar DS, Ratnani H. Effectivity of sambung nyawa leaf extract to inhibit vascular endothelial growth factor expression on endothelials of chorioallantoic membrane. Jurnal Veteriner 2013; 14 (1): 85-90.

Kaneda I, Kubo F, Sakurai H.Antioxidative compounds in the extracts of black rice brans. Journal of Health Science 2006; 52: 495-511.

Kilarski WW, Fuchs PF, Gerwins, Petersson L, Zielinski MS. An in vivo neovascularization assay for screening regulators of angiogenesis and assessing their effects on pre-existing vessels.Angiogenesis Springer 2012; 15: 643-655.

Kristamtini.Mengenal beras hitam dari bantul.Tabloid Sinar Tani 2009.

McDonald MD.Tumor blood vessel dynamics during and after angiogenesis inhibition. Journal of the Federation of American Societies For Experimental Biology2008; 22.

Rafii S.Efficient mobilization and recruitment of marrow-derived endothelial and hematopoietic stem cells by adenoviral vectors expressing angiogenic factors. Gene Therapy 2002; 9: 631-641.

Ribatti D, Gulandris A, Bastaki M, Vacca A, Iurlaro $M$, Roncali L, Presta $M$. New model for the study of angiogenesis and antiangiogenesis in the chick embryo chorioallantoic membrane: the gelatin sponge/chorioallantoic membrane assay. Journal of Vascular Research 1997; 34:455-463.

Ribbati D, Vacca A, Presta M. The discovery of angiogenic factors: a historical review.General Pharmacology 2002;35:227-231.

Salamah N, Sugiyanto, Hartati ME, Hayati F. Antiangiogenic activity of methanolic extract from akar pasak bumi (Eurycoma Longifolia, Jack) on chorioallantoic membrane of chicken embryo induced by bFGF. Majalah Obat Tradisional 2010;15 (1): 1 - 7 .

Saleem U, Ahmad B, Ahmad M, Hussain K, Bukhari NI, Ashraf M. Evaluation of anti-angiogenic activity of latex and extracts of euphorbia helioscopia using chorioallontoic membrane (cam) assay. International Journal of Agriculture \& Biology 2015; 17 (2): 339-344.

Takashi I, Bing, Xu, Yoichi Y, Masaharu N, Tetsuya K.Antioxidant activity of anthocyanin extract from purple black rice. J med food2001; 4 (4) :211-218

Yildiz C,Cetin A, Demirci F,Polat ZA,Kiyan T,Altun A,Cetin M, Yildiz OK, Goze I. Anti-angiogenic effects of diltiazem, imatinib, andbevacizumab in the cam assay.International journal of scientific and research publications2013; 3 (8) :1-8. 